\title{
Microwave assisted solubilization of inclusion bodies
}

\author{
Ishara Datta, Saurabh Gautam and Munishwar N Gupta*
}

\begin{abstract}
Background: Production of recombinant proteins in bacterial hosts often produces insoluble intracellular particles called inclusion bodies. Recovery of active protein from inclusion bodies generally requires their solubilization in chemical denaturants followed by a refolding strategy. The solubilization is carried out with shaking/stirring and takes several hours.

Results: Using inclusion bodies of seven diverse kinds of recombinant proteins [mutants of controller of cell division or death protein B (CcdB), human CD4D12, thioredoxin fusion protein (malETrx), mutants of maltose binding protein (MBP), single chain variable fragment (ScFv) b12 and single chain antigen binding fragment (ScFab) b12 (anti-HIV-1)], it is shown that exposure to microwave irradiation (200 W) for $2 \mathrm{~min}$, solubilized these inclusion bodies completely. This was confirmed by data based upon turbidity measurements at $400 \mathrm{~nm}$ and dynamic light scattering studies. These solubilized inclusion bodies could be refolded correctly in all the cases by known methods. The refolding was confirmed by fluorescence emission spectra and biological activity studies.

Conclusion: Solubilization of the inclusion bodies before refolding is a part of protein production processes for several recombinant proteins which are overexpressed in the bacterial host systems. Our results show that microwave assistance can considerably shorten the process time.
\end{abstract}

Keywords: Solubilization of inclusion bodies, Protein refolding, Microwave assisted reactions, Maltose binding protein, Thioredoxin

\section{Background}

Production of recombinant proteins in bacterial hosts often produces insoluble particles called "inclusion bodies" [1-3]. Recovery of active soluble proteins from these inclusion bodies involves two steps. The first step is the solubilization of the inclusion bodies which involves unfolding of the protein molecules by chemical denaturants [4] and the second step is the refolding step. No single refolding method is universally applicable and hence a large number of strategies have been described in the literature for refolding purposes [2,5-8]. The innovations in the first step have been rather limited [9]. Urea and Guanidinium hydrochloride $(\mathrm{GuHCl})$ are the most frequently employed denaturants $[10,11]$. Some surfactants like cetyltrimethylammonium bromide (CTAB) and sodium dodecyl sulfate (SDS) have been also tried [11-13]. Use of cetyltrimethylammonium chloride (CTAC) has

\footnotetext{
* Correspondence: appliedbiocat@yahoo.co.in

Department of Chemistry, Indian Institute of Technology Delhi, Hauz Khas, New Delhi 110016, India
}

been reported to improve subsequent yields of the refolded proteins [14].

The solubilization step generally requires from 1 to 80 hours [15] and hence constitutes a significant component of process time for production of recombinant proteins [15]. The present work outlines a simple, efficient and fast solubilization procedure. The strategy involves microwave assisted solubilization and takes only 2 minutes.

Microwave assistance is known to facilitate numerous chemical reactions [16], biochemical reactions [17-19], biochemical conjugation $[20,21]$ and protein degradation in proteomics $[19,20]$. Its application for facilitating rapid solubilization of inclusion bodies does not seem to have been described so far. It is shown that the method works well with inclusion bodies of several diverse kinds of recombinant proteins. It is also shown that the refolded proteins obtained from microwave assisted solubilized inclusion bodies are structurally identical to refolded proteins obtained after conventional and longer solubilization steps. The refolded proteins have been 
characterized by fluorescence emission spectra and biological activity assays.

\section{Results and discussion}

The inclusion bodies of MBP224D, MBP264D, CcdBM97K, malETrx, ScFv b12, ScFab b12, and CD4D12 were used for the development of this method. The properties and refolding of these recombinant proteins by a simple precipitation method have been described recently [7]. These chosen proteins were of diverse nature in terms of size, number of disulfide bridges, proneness to aggregation etc. and hence constitute a good representative selection for testing the generic nature of the microwave assisted solubilization method as well.

Turbidity measurements at $400 \mathrm{~nm}$ are generally used for following the extent of solubilization of inclusion bodies [22]. Figure 1 shows the turbidity (as measured at $400 \mathrm{~nm}$ ) of these various inclusion bodies suspended in three common solubilization reagents (urea, $\mathrm{GuHCl}$, SDS) [10-12] and exposed to microwave irradiation for 2 minutes. For comparison, the turbidity of the inclusion bodies suspended in the aqueous buffer (without any denaturant) is also shown in Figure 1. The drastic reduction in the turbidity after microwave treatment points towards solubilization of the inclusion bodies. Visually, these samples appeared to be clear indicating complete solubilization of the inclusion bodies.

It may be noted that even though the inclusion bodies appeared to have become completely soluble, the turbidity

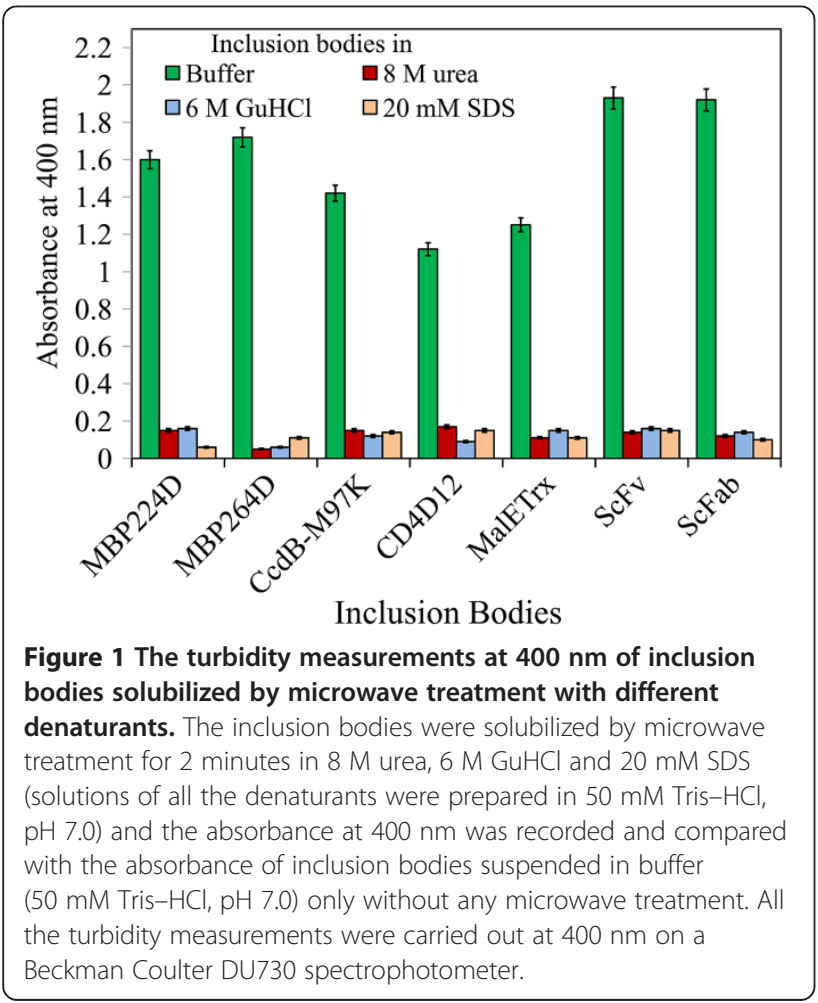

measurements after solubilization (Figure 1) still had some finite values. This result is in agreement with the one reported by Vincentelli [22] with a solubilized protein in $6 \mathrm{M} \mathrm{GuHCl}$.

However, no explanation was offered presumably since the turbidity value was considered insignificant. We decided to investigate this further so as to be sure that the microwave treatment is resulting in complete solubilization of the inclusion bodies.

Table 1 shows the results of the DLS (dynamic light scattering) measurement on the average diameter of the species present in the solutions of $8 \mathrm{M}$ urea, $6 \mathrm{M} \mathrm{GuHCl}$ and $20 \mathrm{mM}$ SDS in the aqueous buffers. These values, larger than expected for these denaturant molecules, indicate clustering or aggregation of these molecules in the solution. In fact, this phenomenon is well known and extensive studies of association of these small molecules in aqueous solutions have been carried out [23-26]. It is also interesting to observe that the microwave exposure (identical conditions as used for protein solubilization) disrupted these associations (Table 1). Except in the case of $8 \mathrm{M}$ urea, this microwave treatment caused extensive dissociation of these clusters or aggregates.

Table 2 gives the data on the average diameter obtained before and after solubilization with microwave treatment in the three denaturants for different inclusion bodies. This data is in broad agreement with the turbidity data (Figure 1).

To further ensure that the microwave treatment (for 2 minutes) has resulted in solubilized or unfolded protein molecules which were similar (if not identical) to protein molecules obtained by conventional solubilization (in 24 hours), the average diameter (measured by DLS) of MBP264D after the solubilization procedures were compared (Figure 2). These values obtained with the three denaturants in both the cases are higher than for unfolded proteins or denaturant molecules (Table 1). This is understandable in view of well known interactions between protein molecules and these denaturants [11]. The differences between the average diameters obtained after the two

Table 1 Average sizes of different denaturants

\begin{tabular}{lll}
\hline Denaturant & $\begin{array}{l}\text { Average diameter } \\
(\mathbf{n m}) \text { before microwave } \\
\text { treatment }\end{array}$ & $\begin{array}{l}\text { Average diameter } \\
(\mathbf{n m}) \text { after microwave } \\
\text { treatment }\end{array}$ \\
\hline $8 \mathrm{M}$ urea & 706 & 587 \\
$6 \mathrm{M} \mathrm{GuHCl}$ & 110 & 9 \\
$20 \mathrm{mM} \mathrm{SDS}$ & 422 & 7 \\
\hline The denaturants $8 \mathrm{M}$ urea, $6 \mathrm{M} \mathrm{GuHCl}$ and $20 \mathrm{mM}$ SDS were prepared in 50 \\
mM Tris-HCl, pH 7.0 and their average sizes (nm) were recorded before and \\
after microwave treatment (for 2 minutes), by dynamic light scattering. This \\
was done as a control experiment. The temperature during microwave \\
solubilization was maintained at $26 \pm 1^{\circ} \mathrm{C}$. The readings were taken in \\
triplicates and the difference among the individual readings was less than $5 \%$.
\end{tabular}


Table 2 Effect of microwave treatment on the average sizes of different inclusion bodies dissolved in different denaturants

\begin{tabular}{|c|c|c|c|c|}
\hline \multirow[t]{2}{*}{$\begin{array}{l}\text { Inclusion } \\
\text { Bodies }\end{array}$} & \multirow{2}{*}{$\begin{array}{l}\text { Average diameter }(\mathrm{nm}) \text { of } \\
\text { inclusion bodies in buffer } \\
\text { before microwave treatment }\end{array}$} & \multicolumn{3}{|c|}{$\begin{array}{l}\text { Average diameter }(\mathrm{nm}) \\
\text { after microwave treatment. }\end{array}$} \\
\hline & & $8 \mathrm{M}$ urea & $6 \mathrm{M} \mathrm{GuHCl}$ & $20 \mathrm{mM}$ SDS \\
\hline MBP224D & 1493 & 390 & 451 & 130 \\
\hline MBP264D & 1504 & 440 & 326 & 130 \\
\hline CcdB-M97K & 751 & 93 & 438 & 62 \\
\hline CD4D12 & 1040 & 284 & 338 & 295 \\
\hline MalETrx & 731 & 120 & 410 & 195 \\
\hline ScFv & 1444 & 615 & 587 & 560 \\
\hline ScFab & 1400 & 884 & 811 & 547 \\
\hline
\end{tabular}

Inclusion bodies of MBP224D, MBP264D, CcdB-M97K, CD4D12, malETrx, ScFv and ScFab, were dissolved in 8 M urea, 6 M GuHCl and 20 mM SDS and subjected to microwave treatment for 2 minutes and the average diameter was recorded. The average diameters of inclusion bodies suspended in $50 \mathrm{mM} \mathrm{Tris-} \mathrm{HCl}$, $\mathrm{pH} 7.0$ (without denaturant) and prior to microwave treatment were also recorded for comparison. The average sizes of the dissolved inclusion bodies were measured by dynamic light scattering. In all the measurements the buffer used was $50 \mathrm{mM}$ Tris- $\mathrm{HCl}, \mathrm{pH} 7.0$. The temperature during microwave solubilization was maintained at $26 \pm 1^{\circ} \mathrm{C}$. Protein concentration in all the cases was $2.0 \mathrm{mg} \cdot \mathrm{mL}^{-1}$. The readings were taken in triplicates and the difference among the individual readings was less than $5 \%$.

solubilization procedures are also not entirely unexpected in view of the effect of microwave on dissociation of the denaturant molecules alone (Table 1).

The kinetics of solubilization of inclusion bodies of MBP264D was followed by DLS measurements (Figure 3). The data confirms that minimum of 2 minutes were required at the chosen microwave power to solubilize inclusion bodies. As mentioned before, the inclusion bodies formed clear solutions at this point. The size remained the same even after 2 minutes.

The microwave solubilized malETrx (thioredoxin fusion protein with signal peptide of maltose binding protein) was refolded by affinity precipitation by using Eudragit

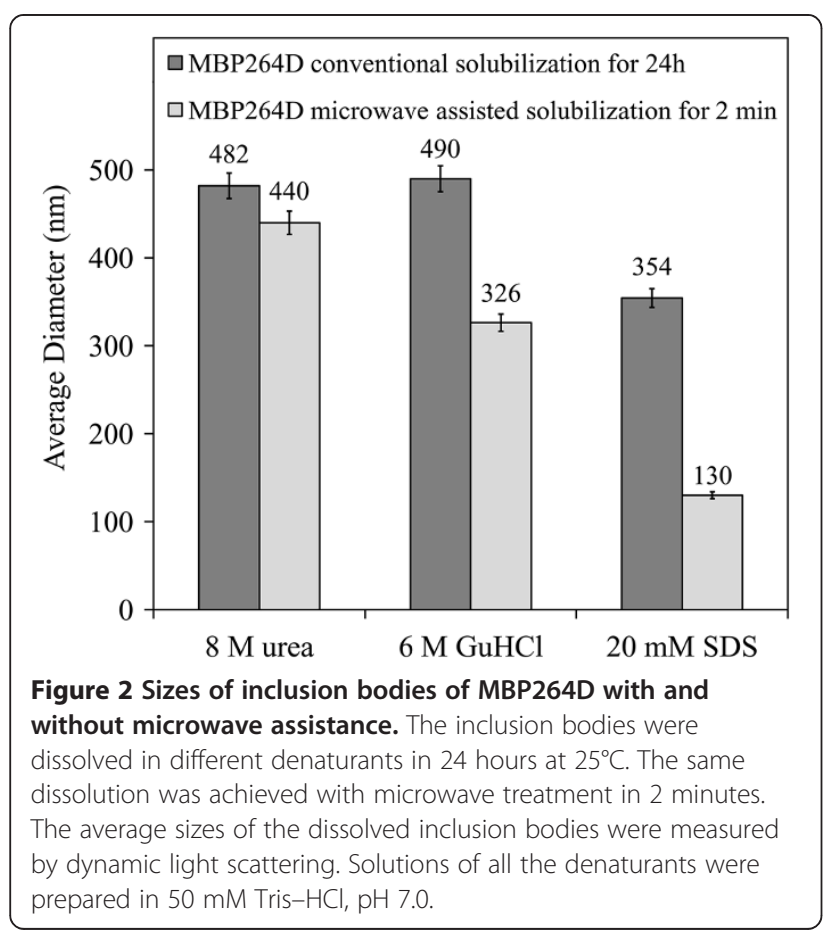

L-100 as a smart polymer [7]. It was also refolded to a similar structure as the earlier one [7] solubilized by $8 \mathrm{M}$ urea, as shown by the fluorescence emission spectra (Figure 4A) with $\lambda_{\max }$ of $342 \mathrm{~nm}$ and insulin aggregation assay (Table 3). CcdB-M97K was also refolded by using Eudragit L-100 [7] and was found to be refolded as shown by the fluorescence emission spectra (Figure 4B). Similarly microwave solubilized inclusion bodies of MBP264D were refolded by affinity precipitation with cationic starch as a smart polymer [7]. The refolded protein was identical to the protein resolubilized without microwave treatment as also described earlier [7], as shown by the fluorescence emission spectra and red shift as well as quenching of the intrinsic fluorescence spectra upon maltose binding (Figure 5) [27].

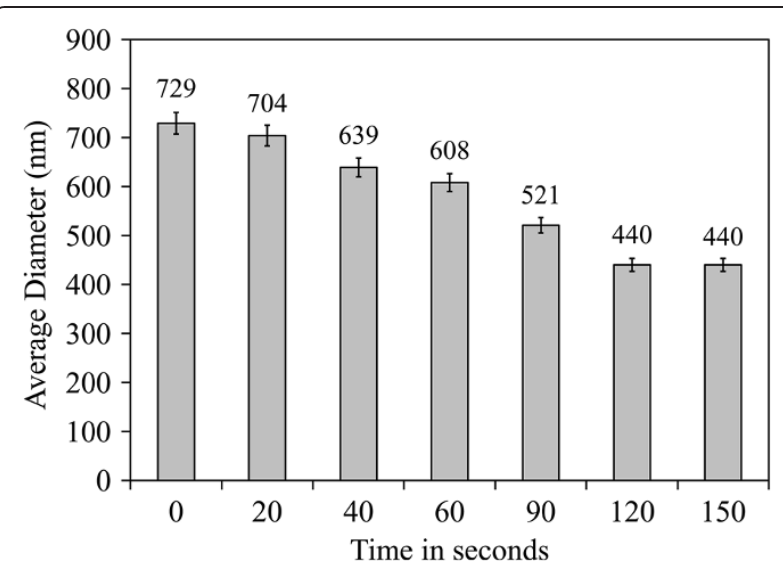

Figure 3 Sizes of inclusion bodies of MBP264D dissolved in 8 M urea with microwave treatment. The inclusion bodies were dissolved in $8 \mathrm{M}$ urea with microwave treatment for varying time intervals. The average sizes of the dissolved inclusion bodies were measured by dynamic light scattering. Solutions were prepared in 50 mM Tris- $-\mathrm{HCl}, \mathrm{pH}$ 7.0. 


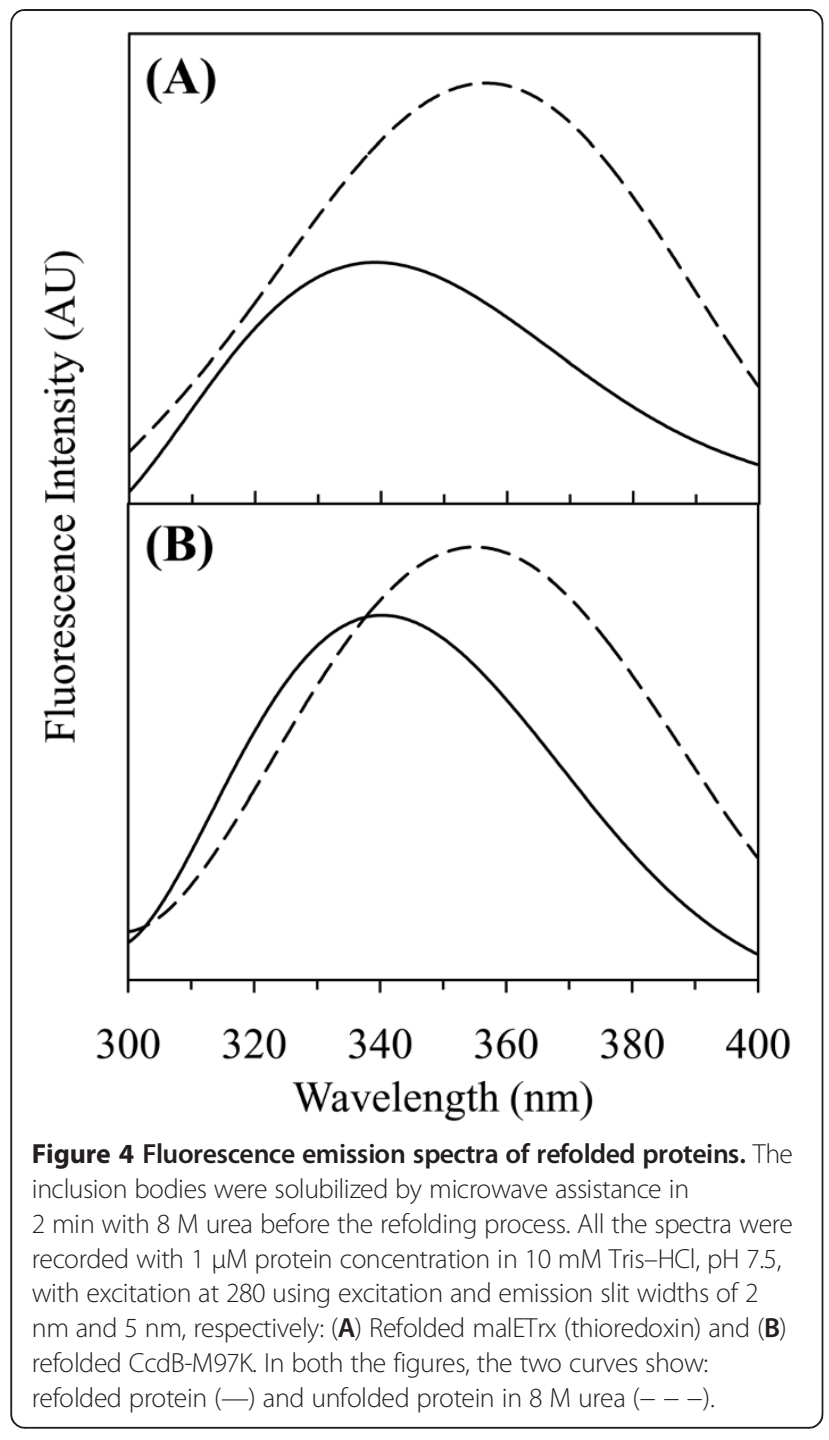

Figure 6 shows the changes in the inclusion bodies during solubilization as seen by a light microscope. Scanning electron microscopy (SEM) and transmission electron microscopy (TEM) techniques could not be used since the denaturants were found to crystallize out during the sample preparation by the standard protocol. Figure 6A shows

Table 3 Insulin aggregation assay for thioredoxin proteins

\begin{tabular}{llll}
\hline & $\begin{array}{l}\text { Protein } \\
\text { (mg) }\end{array}$ & $\begin{array}{l}\text { Activity } \\
\text { (Units) }\end{array}$ & $\begin{array}{l}\text { Specific-Activity } \\
\left(\text { Units } \mathbf{~ m g}^{-1} \text { ) }\right.\end{array}$ \\
\hline $\begin{array}{l}\text { Initial protein taken for refolding } \\
\text { (solubilized inclusion bodies) }\end{array}$ & 0.50 & - & - \\
$\begin{array}{l}\text { Affinity precipitation } \\
\text { refolded malETrx }\end{array}$ & 0.32 & 1.10 & 3.4 \\
\begin{tabular}{l} 
WT-Thioredoxin (Sigma-Aldrich) \\
\hline
\end{tabular} & - & - & 4.0 \\
\hline
\end{tabular}

The experiments were carried out in triplicates and the difference in the individual readings was less than $5 \%$.

${ }^{*}$ One unit will cause a $\Delta \mathrm{A} 650$ of 1.0 in $1 \mathrm{~min}$ at $25^{\circ} \mathrm{C}$.

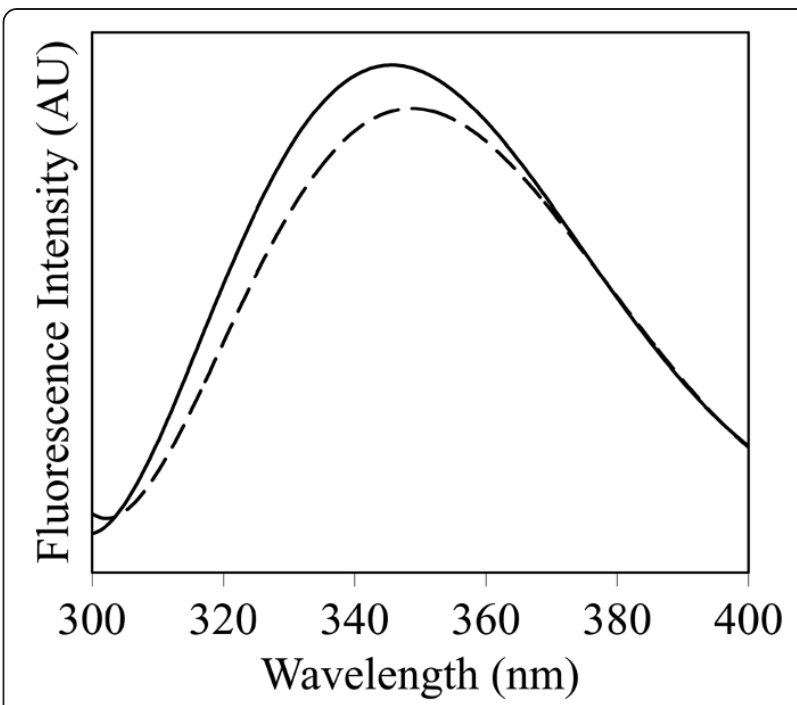

Figure 5 Fluorescence based maltose binding assay for refolded MBP264D. The inclusion bodies were solubilized by microwave assistance in $2 \mathrm{~min}$ with $8 \mathrm{M}$ urea before refolding by using cationic starch as a smart polymer. Fluorescence emission spectra (AU, arbitrary units) were acquired in $10 \mathrm{mM}$ Tris- $\mathrm{HCl}, \mathrm{pH}$ 7.5; using excitation and emission slit widths of $2 \mathrm{~nm}$ and $5 \mathrm{~nm}$, respectively. Protein samples at a concentration of $3.5 \mu \mathrm{g} / \mathrm{mL}^{-1}$ were incubated in Tris buffer (-) and in Tris buffer containing $0.1 \mathrm{mM}$ maltose (- - -) 15 min before spectral acquisition.

the inclusion bodies of MBP264D suspended in the aqueous buffer. Figure 6B shows the way the inclusion bodies looked immediately after adding $8 \mathrm{M}$ urea. Figure $6 \mathrm{C}$ shows partial solubilization after 30 seconds of microwave treatment. Figure $6 \mathrm{D}$ shows that the solubilization was practically complete after 2 minutes. This data further confirms that minimum treatment of 2 minutes by microwave irradiation in a domestic microwave oven led to the complete solubilization of inclusion bodies of several different proteins by the denaturants.

\section{Experimental}

\section{Materials}

Ampicillin, isopropyl- $\beta$-D-thiogalactopyranoside (IPTG), phenylmethanesulfonylfluoride (PMSF) and guanidinium hydrochloride $(\mathrm{GuHCl})$ were purchased from Sigma-Aldrich (St. Louis, MO, USA). Ethylenediaminetetraacetic acid (EDTA) and sodium dodecyl sulfate (SDS) were obtained from Merck (Mumbai, India). Urea (PlusOne grade) was a product of GE Healthcare (Uppsala, Sweden). All other reagents used were of analytical grade.

\section{Over-expression of proteins in E.coli and isolation of inclusion bodies [7]}

E. coli BL21 (DE3) was used for protein expression of malETrx, human CD4D12, mutants of MBP, ScFv b12 and ScFab b12. E. coli CSH501 was used for expressing the $\mathrm{CcdB}$ mutant. The plasmids used for expression of 

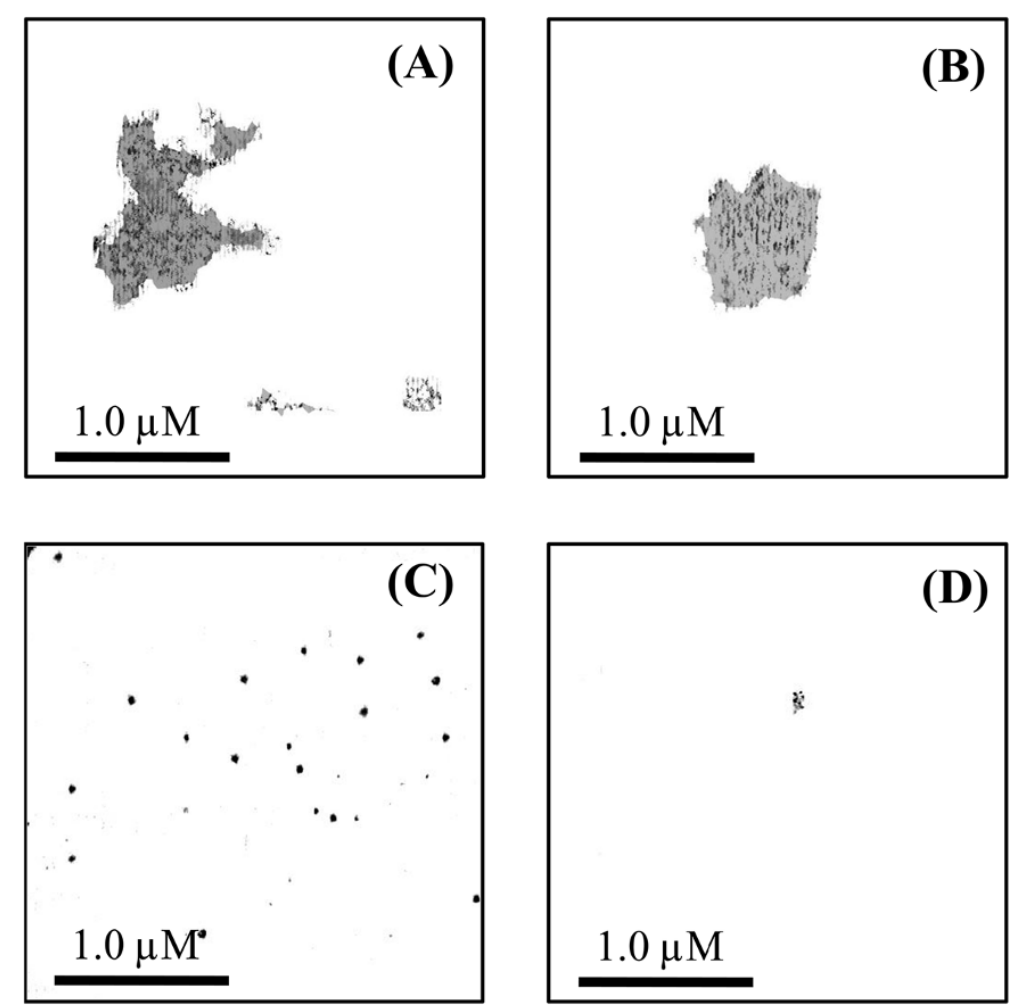

Figure 6 Light microscope images of inclusion bodies of MBP264D. (A) inclusion bodies suspended in $50 \mathrm{mM}$ Tris- $\mathrm{HCl}$, pH 7.0, without any treatment, (B) immediately after adding $8 \mathrm{M}$ urea, (C) subjected to microwave treatment for 30 seconds in $8 \mathrm{M}$ urea and (D) microwave treatment for 60 seconds in $8 \mathrm{M}$ urea. All the images are zoomed images taken on a light microscope (Model: CX21i, Olympus) at 1000x magnification with immersion oil.

these proteins were pBAD24 containing CcdB-M97K, MBP224D and MBP264D inserts, pET20b(+) containing (A14E)malETrx insert, pET28a containing human CD4D12 insert, pET22b(+) containing ScFv b12 insert and pComb containing ScFab b12 insert. The plasmid pBAD24 expressing CcdB mutant M97K was transformed into E. coli CSH501 [28]. A single colony was picked and inoculated into $5 \mathrm{~mL} \mathrm{LB}$ medium containing $100 \mu \mathrm{g} \mathrm{mL}{ }^{-1}$ ampicillin. One percent of primary inoculum was transferred into $1 \mathrm{~L}$ fresh LB broth (amp+) and grown at $37^{\circ} \mathrm{C}$ with shaking at $200 \mathrm{rpm}$ until absorbance at $600 \mathrm{~nm}$ reached 0.8 and then the induction was carried out. This procedure was repeated for the transformation of the plasmid pET20b(+) containing (A14E) malETrx insert (showing leaky expression), pBAD24 containing MBP224D and 264D inserts, pET22b(+) containing $\mathrm{ScFv}$ b12 insert and pComb containing ScFab b12 insert into E. coli BL21 (DE3). The plasmid pET28a expressing CD4D12 was transformed into $E$. coli BL21 (DE3) and $50 \mu \mathrm{g} \mathrm{mL} \mathrm{m}^{-1}$ kanamycin was used as the selection marker. Induction was carried out by adding L-arabinose (0.2\%) in case of CcdB-M97K, MBP224D and MBP264D; $0.5 \mathrm{mM}$ IPTG (final concentration) in case of malETrx and CD4D12; and $1 \mathrm{mM}$ IPTG (final concentration) in case of ScFv b12 and ScFab b12, and the culture was further grown under similar conditions for 12 hours at $37^{\circ} \mathrm{C}$ with shaking at $200 \mathrm{rpm}$. Cells were harvested, sonicated in resuspension buffer (for CcdB mutant, $50 \mathrm{mM}$ Tris$\mathrm{HCl}, \mathrm{pH}$ 8.0/1 mM EDTA/10\% glycerol/200 $\mu \mathrm{M}$ PMSF; for malETrx, MBP mutants, ScFv b12 and ScFab b12, $50 \mathrm{mM}$ Tris- $\mathrm{HCl}, \mathrm{pH}$ 7.0/150 mM NaCl/1 mM EDTA/ $100 \mu \mathrm{M}$ PMSF; for CD4D12, $50 \mathrm{mM}$ PBS, pH 7.4/ $100 \mu \mathrm{M}$ PMSF) 10 times with 30 seconds pulses on ice, and centrifuged at $9000 \times \mathrm{g}$ for 30 minutes at $4^{\circ} \mathrm{C}$. The inclusion body pellet was washed (thrice) with washing buffer (50 mM PBS, pH 7.4/0.5\% Triton X-100) and centrifuged at $9000 \times \mathrm{g}$ for 30 minutes at $4^{\circ} \mathrm{C}$.

\section{Inclusion bodies solubilization with microwave}

The inclusion bodies of MBP224D, MBP264D CcdBM97K, CD4D12, malETrx, ScFv and ScFab were suspended in solutions of different denaturants (which included $8 \mathrm{M}$ urea, $6 \mathrm{M} \mathrm{GuHCl}$ and $20 \mathrm{mM}$ SDS) in 50 $\mathrm{mM}$ Tris- $\mathrm{HCl}, \mathrm{pH} 7.0$ in a final volume of $3 \mathrm{~mL}$ in an open glass vial and microwave treatment was carried out by placing the reaction mixture inside a domestic microwave oven (Model: NN-K543WF, Panasonic) along with a glass beaker containing $100 \mathrm{ml}$ of water. This was done to 
avoid overheating of samples. To maintain the temperature, the samples were exposed for 10 seconds in a microwave and then kept outside for 10 seconds in an ice bath. The reaction mixture was exposed to microwave radiations at low power $(200 \mathrm{~W})$ with temperature maintained between 25 and $30^{\circ} \mathrm{C}$.

\section{Turbidity measurements}

The turbidity at $400 \mathrm{~nm}$ was measured by Beckman Coulter DU730 spectrophotometer [22].

\section{Dynamic light scattering (DLS) measurements}

Dynamic light scattering measurements were performed at $25^{\circ} \mathrm{C}$ in laser-spectroscatter 201 by RiNA $\mathrm{GmbH}$ (Berlin, Germany). Data analysis was done using PMgr v3.01p17 software supplied with the instrument. The average diameter of the suspension of inclusion bodies was recorded before and after solubilization. The solubilization was carried out both by microwave irradiation for 2 minutes and conventional procedure which consisted of suspending the inclusion bodies in $8 \mathrm{M}$ urea and incubating these at $25^{\circ} \mathrm{C}$ on a shaker at $200 \mathrm{rpm}$ for 24 hours [15].

\section{Estimation of protein concentration}

The protein concentration in all the cases was estimated by the dye binding method using bovine serum albumin as the standard protein [29].

\section{Fluorescence measurements}

Fluorescence spectra of the refolded proteins were recorded on a Cary Eclipse, Varian spectrofluorimeter (Mulgrave, Australia) at $25^{\circ} \mathrm{C}$ using a 1-cm cuvette. Typically, $0.5-1.0 \mu \mathrm{M}$ protein in $10 \mathrm{mM}$ Tris $-\mathrm{HCl}, \mathrm{pH} 7.5$, was used and the fluorescence emission spectra were recorded from $300 \mathrm{~nm}$ to $400 \mathrm{~nm}$ upon excitation at 280 $\mathrm{nm}$. The excitation and emission slit widths were kept at $2 \mathrm{~nm}$ and $5 \mathrm{~nm}$, respectively. All fluorescence spectra were normalized and corrected for buffer contributions.

\section{Assay for thioredoxin}

The activity of thioredoxin was assayed by the insulin aggregation assay [30].

\section{Binding assay for MBP}

The binding of maltose to MBP was assayed fluorimetrically by observing a red shift and quenching in the intrinsic tryptophan of MBP upon maltose binding [27].

\section{Microscopic examination}

Images were taken on a light microscope (Model: CX21i, Olympus) microscope with an Olympus camera attached to the microscope. The samples were viewed under
1000X magnification (100X objective lens and 10X eye piece) which was obtained by using immersion oil.

\section{Refolding of solubilized inclusion bodies}

The solubilized inclusion bodies were refolded by using smart polymers as described previously [7]. The essential steps were as follows:

Different aliquots of solubilized inclusion bodies were incubated with $0.2 \mathrm{~mL}$ of $2 \%(\mathrm{w} / \mathrm{v})$ Eudragit L-100 (final concentration, $0.2 \%$, w/v) for CcdB-M97K and malETrx and $0.3 \mathrm{~mL}$ of $2 \%(\mathrm{w} / \mathrm{v})$ cationic starch (final concentration, $0.3 \%, \mathrm{w} / \mathrm{v}$ ) for MBP264D, and the final volume was made up to $2 \mathrm{~mL}$ with $50 \mathrm{mM}$ Tris- $\mathrm{HCl}, \mathrm{pH}$ 7.5. The final protein concentration was $0.2-2.5 \mathrm{mg} \cdot \mathrm{mL}^{-1}$. After incubation at $25^{\circ} \mathrm{C}$ for 1 hour with shaking at $200 \mathrm{rpm}$, the polymer-protein complex was precipitated by lowering the $\mathrm{pH}$ to 4.0 with $2 \mathrm{M}$ acetic acid in case of Eudragit L-100 and by the addition of $10 \%(\mathrm{w} / \mathrm{v})$ PEG and $50 \mathrm{mM} \mathrm{CaCl}_{2}$ [stock solutions of PEG $(40 \%, \mathrm{w} / \mathrm{v})$ and $\mathrm{CaCl}_{2}(1 \mathrm{M})$ were made in distilled water] for cationic starch. The precipitate was separated from the unbound protein in the supernatant by centrifugation $(10000 \times g, 10$ minutes) at room temperature. The precipitate was then washed twice with $0.01 \mathrm{M}$ acetate buffer, $\mathrm{pH} 4.0$ for Eudragit L-100 and $50 \mathrm{mM}$ Tris- $\mathrm{HCl}, \mathrm{pH}$ 7.5 for cationic starch. The bound protein was dissociated from the polymer by suspending the polymerprotein complex in $70 \%(\mathrm{v} / \mathrm{v})$ ethylene glycol solution made in $50 \mathrm{mM}$ Tris- $\mathrm{HCl}, \mathrm{pH} 7.5$ for Eudragit L-100 and chilled $1 \mathrm{M} \mathrm{NaCl}$ (in $50 \mathrm{mM}$ Tris- $\mathrm{HCl}, \mathrm{pH}$ 7.5) for cationic starch and incubating at $4{ }^{\circ} \mathrm{C}$ for 1 hour with shaking at $150 \mathrm{rpm}$. The supernatant collected after centrifugation at $10000 \times g$ for 10 minutes at $4^{\circ} \mathrm{C}$, was used for spectroscopic measurements and activity assays. All measurements were carried out after removal of the dissociating agent by membrane filtration (Amicon Ultra15 3K, Millipore).

\section{Conclusions}

Microwave irradiations cause continuous realignment of the polar molecules with the changing field. This causes solutions containing polar molecules (such as water) to get heated. However, as opposed to simple heating, the energy input is more efficient and happens over a shorter period of time. Hence, many workers describe such effects as "non-thermal effects" of the microwave irradiations. Hence, exposure to microwave irradiations is known to accelerate many processes $[16,17]$.

The results obtained with seven inclusion bodies of diverse kinds of proteins show that a minimum exposure to microwave radiation for just 2 minutes is enough to solubilize inclusion bodies irrespective of which of the commonly used denaturants is used. These results have been obtained with a commonly available ordinary domestic 
microwave oven. Such microwave ovens are available in all biochemistry laboratories. Wherever available, a microwave with a temperature control can also be utilized. The results further indicate the method described here did not merely solubilize the inclusion bodies but led to unfolded protein molecules which could be refolded just as well as those obtained by existing procedures which require longer duration of time. Production of many industrially important proteins (including pharmaceutical proteins) requires solubilization of inclusion bodies followed by a refolding step. The method outlined here would make the whole process shorter and possibly more economical. As much as the use of microwave in case of conventional methods is considered a strong component of green chemistry, the method described here can be considered as a part of initiative to develop greener production processes [31].

\section{Competing interests}

The authors declare that they have no competing interests.

\section{Authors' contributions}

ID and SG carried out the experimental work. MNG designed the study and was involved in all discussions, interpretation of data and writing the manuscript. All authors read and approved the final manuscript.

\section{Acknowledgements}

We acknowledge financial support provided by Department of Biotechnology (DBT) [Grant number: BT/PR14103/BRB/10/808/2010] and Department of Science and Technology (DST), Government of India. Financial support provided by Council of Scientific and Industrial Research to SG in the form of senior Research Fellowship is also gratefully acknowledged. We also thank Professor Raghavan Varadarajan (Indian Institute of Science, Bangalore) for providing the clones of MBP224D, MBP264D, CcdB-M97K, malETrx, ScFv b12, ScFab b12, and CD4D12.

Received: 14 January 2013 Accepted: 26 March 2013

Published: 22 May 2013

\section{References}

1. Walker SG, Lyddiatt A: Aqueous two-phase systems as an alternative process route for the fractionation of small inclusion bodies. J Chromatogr B 1998, 711:185-194.

2. Middelberg APJ: Preparative protein refolding. Trends Biotechnol 2002, 20:437-443.

3. Upadhyay AK, Murmu A, Singh A, Panda AK: Kinetics of Inclusion Body Formation and Its Correlation with the Characteristics of Protein Aggregates in Escherichia coli. PLoS One 2012, 7(3):e33951. doi:10.1371/ journal.pone.0033951.

4. Vallejo LF, Rinas U: Strategies for the recovery of active proteins through refolding of bacterial inclusion body proteins. Microb Cell Fact 2004, 3:11

5. Cleland JL, Builder SE, Swartz JR, Winkler M, Chang JY, Wang DI: Polyethylene glycol enhanced protein refolding. Biotechnology NY 1992, 10:1013-1019.

6. Basu A, Li X, Leong SS: Refolding of proteins from inclusion bodies: rational design and recipes. App/ Microbiol Biotechnol 2011, 92:241-251.

7. Gautam S, Dubey P, Singh P, Kesavardhana S, Varadarajan R, Gupta MN: Smart polymer mediated purification and recovery of active proteins from inclusion bodies. J Chromatogr A 2012, 1235:10-25.

8. Burgess RR: Refolding solubilized inclusion body proteins. Methods Enzymol 2009, 463:259-282.

9. Singh SM, Panda AK: Solubilization and refolding of bacterial inclusion body proteins. J Biosci Bioeng 2005, 99:303-310.

10. Marston FA, Hartley DL: Solubilization of protein aggregates. Methods Enzymol 1990, 182:264-276.

11. Hamada H, Arakawa T, Shiraki K: Effect of additives on protein aggregation. Curr Pharm Biotechnol 2009, 10:400-407.
12. Stöckel J, Döring K, Malotka J, Jähnig F, Dornmair K: Pathway of detergentmediated and peptide ligand-mediated refolding of heterodimeric class II major histocompatibility complex (MHC) molecules. Eur J Biochem 1997, 248:684-691.

13. Sarramegna V, Muller I, Mousseau G, Froment C, Monsarrat B, Milon A, Talmont F: Solubilization, purification, and mass spectrometry analysis of the human mu-opioid receptor expressed in Pichia pastoris. Protein Expr Purif 2005, 43:85-93.

14. Puri NK, Crivelli E, Cardamone M, Fiddes R, Bertolini J, Ninham B, Brandon MR: Solubilization of growth hormone and other recombinant proteins from Escherichia coli inclusion bodies by using a cationic surfactant. Biochem J 1992, 285:871-879.

15. Fischer B, Sumner I, Goodenough P: Isolation, renaturation, and formation of disulfide bonds of eukaryotic proteins expressed in Escherichia coli as inclusion bodies. Biotechnol Bioeng 1993, 41:3-13.

16. Polshettiwar V, Varma RS: Microwave-assisted organic synthesis and transformations using benign reaction media. Acc Chem Res 2008, 41:629-639.

17. Roy I, Gupta MN: Applications of microwaves in biological sciences. Curr Sci 2003, 80:1685-1693.

18. Roy I, Gupta MN: Non thermal effects of microwaves on protease catalyzed esterification and trans-esterification. Tetrahedron 2003, 59:5431-5436.

19. Loupy A, Varma RS: Microwave effects in organic synthesis: Mechanistic and reaction medium considerations. Chem Inform 2007, 38: .

20. Hayes BL: Microwave synthesis chemistry at the speed of light. NC: CEM Publishing; 2002.

21. Solanki K, Mondal K, Gupta MN: Microwave-assisted preparation of affinity medium. Anal Biochem 2007, 360:123-129.

22. Vincentelli R, Canaan S, Campanacci V, Valencia C, Maurin D, Frassinetti F, Scappucini-Calvo L, Bourne Y, Cambillau C, Bignon C: High-throughput automated refolding screening of inclusion bodies. Protein Sci 2004, 13:2782-2792

23. Sokolic F, Idrissi A, Perera A: Concentrated aqueous urea solutions: A molecular dynamics study of different models. J Chem Phys 2002, 116:1636-1646.

24. Mason PE, Neilson GW, Enderby JE, Saboungi ML, Dempsey CE, MacKerell $A D$, Brady JW: The structure of aqueous guanidinium chloride solutions. J Am Chem Soc 2004, 126:11462-11470.

25. O'Brien EP, Dima Rl, Brooks B, Thirumalai D: Interactions between hydrophobic and ionic solutes in aqueous guanidinium chloride and urea solutions: lessons for protein denaturation mechanism. J Am Chem Soc 2007, 129:7346-7353.

26. Stumpe $M C$, Grubmüller H: Aqueous urea solutions: structure, energetics, and urea aggregation. J Phys Chem B 2007, 111:6220-6228.

27. Szmelcman S, Schwartz M, Silhavy TJ, Boos W: Maltose transport in Escherichia coli K12. A comparison of transport kinetics in wild-type and lambda-resistant mutants as measured by fluorescence quenching. Eur J Biochem 1976, 65:13-19.

28. Chakshusmathi G, Mondal K, Lakshmi GS, Singh G, Roy A, Ch RB, Madhusudhanan S, Varadarajan R: Design of temperature-sensitive mutants solely from amino acid sequence. Proc Natl Acad Sci U S A 2004 101:7925-7930.

29. Bradford MM: A rapid and sensitive method for the quantitation of microgram quantities of protein utilizing the principle of protein-dye binding. Anal Biochem 1976, 72:248-254.

30. Holmgren A: Thioredoxin catalyzes the reduction of insulin disulfides by dithiothreitol and dihydrolipoamide. J Biol Chem 1979, 254:9627-9632.

31. Ulber R: Sell: Advances in biochemical engineering/Biotechnology, White Biotechnology, Volume 105. Heidelberg: Springer; 2007.

doi:10.1186/2043-7129-1-2

Cite this article as: Datta et al: Microwave assisted solubilization of inclusion bodies. Sustainable Chemical Processes 2013 1:2. 